\title{
ON PREFIXES AND ACTIONALITY IN CLASSICAL AND LATE LATIN
}

\author{
GERD HAVERLING
}

\begin{abstract}
In Early and Classical Latin, we encounter a rich and complex system in which prefixes are used to render verbs telic and to emphasise the beginning or end of a process or of an activity, and in which the opposition between non-dynamicity and dynamicity or between transitivity and intransitivity is expressed by various suffixes. In the perfect there is an opposition between non-dynamic unprefixed verbs and dynamic prefixed ones. In the later centuries this system breaks down, and there is a blurring of the semantic difference between the prefixed and unprefixed verbs and often also of that between the prefixes themselves. New verbs are formed to replace old verbs that have lost their old functions. These changes pervade the whole verbal system in Latin and affect the semantic relationship between the perfect and imperfect tenses. In Romance, the definite and indefinite articles express the functions previously expressed by the various actional forms.
\end{abstract}

\section{Introduction}

Verbs and phrases containing a verb express different kinds of actionality. They may, for instance, indicate a non-dynamic State, an atelic Activity, a telic Accomplishment or a momentaneous Achievement. ${ }^{1}$ In the development from Early to Late Latin there is a gradual change in the way some such semantic features are expressed. ${ }^{2}$ In Early and Classical Latin (ca. 200 BCEca. $200 \mathrm{CE}$ ) there is an opposition between unprefixed verbs indicating an atelic Activity and prefixed verbs used in a telic sense, for instance between suadeo 'try to persuade' and persuadeo 'persuade' (1a). In Late Latin (ca. $200 \mathrm{CE}-\mathrm{ca} .600 \mathrm{CE}$ ), however, these semantic oppositions are blurred. Thus in the official translation of the Bible, the so-called Versio Vulgata, which was revised by St. Jerome around $400 \mathrm{CE}$, we may encounter the prefixed

1 See e.g., Vendler (1957; 1967), Comrie (1978, 41ff), Smith (1997, 22ff), Johanson (2000, 55ff), Bertinetto-Delfitto (2000); cf. also Haverling (2000, 22ff).

2 Such differences are often expressed by derivational features as opposed to aspectual differences, which tend to be inflectional: see Bybee (1985, 102) and Bybee et al. (1994, 57ff).

1216-8076/03/\$20.00 (c) 2003 Akadémiai Kiadó, Budapest 
persuadeo in the sense 'try to persuade' and the unprefixed suadeo in the sense 'persuade' (1b):

(1) (a) 2nd c. BCE: suadeo 'try to persuade' (e.g., Plaut. Stich. 608) - persuadeo 'persuade' (e.g., Plaut. Truc. 200)

(b) 4th c. CE: suadeo 'persuade' (Vulg. Act. 21.14) - persuadeo 'try to persuade' (e.g., Vulg. Ruth 1.18)

In Early and Classical Latin edo means 'eat' or 'eat (some) of' and comedo 'eat up' (2a), and bibo means 'drink' or 'drink of' and ebibo means 'drink up' (3). But in Late Latin, for instance in the Versio Vulgata, we frequently encounter the prefixed verb comedo in the sense 'eat, eat of' $(2 \mathrm{~b}):^{3}$

(2) (a) 2nd c. BCE: edo 'eat, eat (some) of' (e.g., Plaut. Capt. 77) - comedo 'eat up' (e.g., Plaut. Most. 559)

(b) 4th c. CE: comedo 'eat (some) of' (e.g., Vulg. Gen. 2.16-17)

(3) 2nd c. BCE: bibo 'drink, drink of' (e.g., Cato Orat. frg. 221) - ebibo 'drink up' (e.g., Ter. Haut. 255)

These changes are found in the perfectum tenses too. In the earlier periods of Latin the unprefixed perfect tense form tacui means 'have been silent' or 'was silent' and the prefixed form conticui 'have fallen silent' or 'stopped talking' (4a). The earliest dynamic examples of the form tacui 'stopped talking' are met with in Late Latin; in the same period we also have some examples of a hypercorrect use of the prefixed forms, for instance conticui in the sense 'have been silent' (4b):

(4) (a) 2nd c. BCE: tacui 'have been silent, was silent' (e.g., Plaut. Truc. 817) - conticui 'stopped talking' (e.g., Plaut. Asin. 448)

(b) 4th c. CE: tacui 'stopped talking' (e.g., Amm. 16.6.3) - conticui 'have been silent, was silent' (e.g., Symm. Epist. 5.89)

In Late Latin - especially in the literary language - the words look very much the same as before, but in several cases their semantic functions have changed. Due to these changes new kinds of word formation are introduced, as well as new ways of using some of the old words. These changes are presumably connected with other changes in the language, for instance in the tense system and in the development of articles in Romance.

3 See Haverling (1994; 2000, 205ff).

${ }^{4}$ See Haverling (1994; 2000, 218ff, 224f). 


\section{Actionality and prefixes from Early to Late Latin}

The changes in the way prefixes express various forms of actionality are clearly illustrated by the development of the $s c o$-verbs in Latin. The $s c o$-suffix is very productive in Latin (there are over 700 such verbs from the earliest attestations of the language to after $600 \mathrm{CE}$ ) and occurs in several different kinds of word formation $(5 \mathrm{a}-\mathrm{f})$. It is found in some verbs of Indo-European descent like nosco or posco (5a), in verbs formed from transitive verbs like augesco (5b), in verbs formed from intransitive and dynamic verbs like permanasco $(5 \mathrm{c})$, in those formed from non-dynamic verbs like aresco (5d), and in verbs formed from adjectives and nouns like siccesco and silvesco $(5 \mathrm{e}-\mathrm{f}):^{5}$

(5) (a) *ghneh ${ }_{3}+-s \hat{k}->$ nosco 'try to get to know'; *prek-sk- $>$ posco 'ask for, demand'

(b) augeo 'increase, intensify' - augesco 'increase, grow'

(c) permano 'flow through, seep, percolate' — permanasco 'seep through gradually, penetrate'

(d) areo 'am dry' — aresco 'become drier, am drying, dry'

(e) siccus 'dry' — siccesco 'become drier, am drying, dry'

(f) silva 'forest' - silvesco 'become like a forest, put forth thick growth, bush out'

The most productive category is $(5 \mathrm{~d})$, the verbs formed from the statives which incorporate the Indo-European suffix $*_{-} e h_{1}$. This suffix, which often interrelates in this way with the $s c o$-suffix, is found in verbs indicating states which in many other languages are described by an adjective and a verb meaning 'to be'. Common expressions for 'is hot' or 'is red' in Early and Classical Latin are simple verbal forms such as calet and rubet. As the original function of the stative suffix disappears in Vulgar Late Latin and in Romance, such verbs are replaced by the combination of an adjective and the verb meaning 'to be', i.e., calet 'is hot' is replaced by expressions like calidum est. ${ }^{6}$

\subsection{Actionality in Early and Classical Latin}

The semantic opposition between atelic unprefixed verbs and telic prefixed ones could be observed in Classical Latin in the way such verbs are used with expressions indicating how long a certain situation lasted or in what length of

5 See Keller (1992) and Haverling (2000, e.g., 137ff); and also Leumann (1977, §407) and Rix (1998, e.g., 149f, 229f, 245, 442f).

6 See e.g., Leumann (1977, §410.2.c and d), Väänänen (1981, §314) and Lehmann (1995). 
time a certain result was achieved. We have unprefixed verbs with durative temporal expressions like duos menses 'for two months' (6a), and prefixed verbs with completive temporal expressions like quindecim diebus 'in fifteen days' $(6 \mathrm{~b}):^{7}$

(6) (a) duos menses ut siccescat 'that it may be drying for two months' (Vitr. 5.12.4)

(b) quindecim diebus ... exarescere 'become dry in fifteen days' (Varro Rust. 1.32.1)

Another example of this is found in the use of prefixed and unprefixed verbs with the conjunction dum meaning 'while, as long as' with an unprefixed verb (7a) and 'until' with a prefixed verb $(7 \mathrm{~b}):^{8}$

(7) (a) dum haec silescunt turbae ... 'while these troubles are calming down' (Ter. Ad. 785)

(b) dum haec consilescunt turbae ... 'until these troubles calm down' (Plaut. Mil. 583)

Common to all of the functions in which the $s c o$-suffix occurs is the fundamentally dynamic and atelic character of the suffix. To express the telic sense, in other words to indicate that a transformation takes place, Early and Classical Latin needs a prefix; for this reason we find in some cases only prefixed verbs, for instance conticesco 'stop talking' and obmutesco 'become dumb' (8a-b): ${ }^{9}$

(8) (a) taceo 'be silent, say nothing' — conticesco 'stop talking'

(b) mutus 'dumb, speechless, silent, mute' — obmutesco 'become dumb, speechless'

In several cases we find an opposition between a non-dynamic verb indicating a State and a prefixed sco-verb indicating a change from one State to another, for instance dormio and condormisco 'fall asleep' (9a) and taceo and conticesco 'stop talking' (10a). Latin, as opposed for instance to Gothic, usually needs a dynamic suffix to turn a non-dynamic verb into one which indicates a change of this kind; in Gothic the prefix ga- alone suffices to do this $(9 \mathrm{~b}, 10 \mathrm{~b})$. The unsuffixed Latin verb condormio means 'to be fast asleep'

7 See Haverling (2000, 61ff); cf. e.g., Smith (1997, 27f), Johanson (2000, 61, 64, 73f), Bertinetto - Delfitto (2000, 199ff).

8 See Haverling (2000, 70ff); cf. Hofmann-Szantyr (1965, §§329-330).

9 See Haverling (2000, e.g., 1, 138, 147, 166-8, 175, 191, 205). Sometimes we find nondynamic verbs in the imperative (e.g., tace 'be silent!' or Ne time 'don't be afraid!'): what is under control in such cases is the change into a state and not the maintenance of it; hence these examples do not show that the verbs have a dynamic or telic function; see Haverling (2000, 47ff); cf. Pinkster (1990, 17) and Smith $(1997,18)$. 
and is found in prose (9a), whereas conticeo means 'stop talking' and is found in poetry $(10 \mathrm{a}):^{10}$

(9) (a) Latin: dormio 'am asleep' (2nd c. BCE) — condormisco 'fall asleep' (2nd c. BC) condormio 'am fast asleep' (1st c. CE, prose)

(b) Gothic: slepan 'sleep' — gaslepan 'fall asleep'

(10) (a) taceo 'am silent, say nothing' (2nd c. BCE) — conticesco 'stop talking' (2nd c. BCE) - conticeo 'stop talking' (1st c. CE, poetry)

(b) Gothic: slawan 'be silent' — gaslawan 'fall silent'; Pahan 'be silent' — gaPahan 'stop talking, fall silent'

There is a certain number of prefixed but unsuffixed verbs which like conticeo have a poetic character in Classical Latin. ${ }^{11}$

The various prefixes change the semantic function of the sco-verbs in different ways and often interrelate with each other. The prefix ex-, which indicates that an action is brought to its conclusion, often interrelates with in-, which indicates the entrance into it. The unprefixed verbs in $(11 \mathrm{a}-\mathrm{c})$ are generally used to describe ongoing processes in nature, such as the changing colours at dawn (rubesco, albesco) or in someone's hair as the years pass (albesco); the verbs prefixed with ex- describe changes from one state to another (exaresco) and in several cases changes in colour that reflect a change in the state of a person's emotions (erubesco, exalbesco); and the verbs prefixed with in- indicate that the change starts and that it takes place to some extent (inaresco, irrubesco, inalbesco): $:^{12}$

(11) (a) aresco 'am drying' — inaresco 'start becoming dry, become somewhat dry' exaresco 'become totally dry, dry out'

(b) rubesco 'grow red, am growing red' — irrubesco 'turn reddish, somewhat red' erubesco 'turn red (in the face because of shame and embarrassment)'

(c) albesco 'grow white, pale, am growing white' — inalbesco 'become somewhat white' - exalbesco 'turn white or pale (in the face because of fear)'

The prefix con- often interrelates with $a d-(12 \mathrm{a}-\mathrm{b})$. The unprefixed verbs usually describe ongoing activities or processes. An exception is suesco: this is telic and first occurs in the historian Tacitus (ca. $100 \mathrm{CE}$ ), who probably

10 On the Latin con- see Haverling (2000, 251-72); cf. also Rosén (1992); on the Gothic prefix ga- see e.g., Josephson (1977) and Lloyd (1979).

11 See Haverling (2000, 265f, 275ff, 308ff, 457).

12 For the examples see Haverling (2000, e.g., 296ff, 328ff); cf. also Haverling (1996a). 
uses it because of its poetic character (unprefixed verbs which are used in the sense of the prefixed ones are often regarded as poetic). ${ }^{13}$ On the other hand, the verbs prefixed with con- indicate a change from one state to another, without emphasising the beginning or end of that change, and those with $a d$ - a gradual change that starts and goes on for some time. The state of knowing or being used to something may be expressed by the perfect tense forms novi and consuevi: $:^{14}$

(12) (a) nosco 'am investigating, studying, trying to find out about' - cognosco 'get to know' - agnosco 'get to know gradually, identify'; novi 'know'

(b) suesco 'get used to' (poetic) — adsuesco 'get used to gradually, get more and more used to' - consuesco 'get used to'; consuevi 'am used to'

In other words, it is not the so-called 'inchoative' sco-suffix, but the prefixes often combined with it, which cause these verbs to indicate a change of state. ${ }^{15}$

The semantic opposition between prefixed and unprefixed dynamic forms also applies to the perfectum tenses. In the earlier periods of Latin we find the unprefixed perfect tense form tacui in the sense 'I have been silent' with the adverb adhuc 'so far' and in the phrase cum tacuisset 'as he had been silent, had not said anything' (13a); the prefixed form conticui means 'I have fallen silent' or 'I stopped talking' and cum conticuisset 'as he had stopped talking' (13b):

(13) (a) 2nd c. BCE: tacui adhuc 'so far I have been silent' (Plaut. Truc. 817) 1st c. BCE: multos cum tacuisset annos 'had been silent for many years' (Cic. Brut. 226)

(b) 2nd c. BCE: tandem ... conticuit 'he finally stopped talking' (Plaut. Asin. 447-448) 1st c. BCE: cum conticuisset 'had stopped talking' (Varro Rust. 1.49.1)

The general rule that unprefixed perfect tense forms like calui and rubui are non-dynamic is observed in Classical prose, where prefixed forms such as

13 On the poetic character of unprefixed words cf. Haverling (2000, e.g., 143f, 220, 229, 231). Several other Roman historians, like Tacitus, used a poetic and somewhat archaic kind of language, because they considered it suitable for the august matter they were dealing with.

14 See Haverling (2000, e.g., 254, 256, 277f, 280f); cf. also Haverling (1996b).

15 See Haverling (2000, e.g., 40, 247ff, 392ff). Somewhat inaccurate descriptions of the function of the Latin $s c o$-suffix are common in the linguistic literature (cf. e.g., Kuryłowicz 1964, 107 and Bybee 1985, 147ff) as a result of unclear and sometimes incorrect descriptions in the handbooks on Latin (cf. e.g., Leumann 1977, §407.II.A.1); on the discussion of the suffix see Haverling (2000, 3-9).

Acta Linguistica Hungarica 50, 2003 
incalui/concalui and irrubui/erubui are used in the dynamic sense (14a-b); but in poetry there is an increasing use of unprefixed forms of the type in a dynamic function $(14 \mathrm{c}):^{16}$

(14) (a) prose or neutral: calui 'was warm' - incalui 'became somewhat warm' — concalui 'became warm'

(b) prose or neutral: rubui 'was red' - irrubui 'became somewhat red' - erubui 'turned red'

(c) poetic: calui 'became warm' — rubui 'turned red'

This is only a very rough picture of how the system works in Classical Latin; for first, there are more prefixes than the ones dealt with here; and second, each prefix may occur in more than one function and often the prefixes overlap the functions of one another. The prefix re-, for example, generally has the sense 'back, again, anew', as in recognosco 'reconsider something previously known' (15a); but it also overlaps with con in the verb rescisco 'get to know of (a fact not previously suspected)' (15b), so that we can compare in Plautus the phrases ne uxor resciscat (15b) and ne uxor cognoscat (15c): ${ }^{17}$

(15) (a) recognosco 'reconsider (something previously known)' (e.g., Cic. Verr. I 15 Neque enim mihi videtur haec multitudo, quae ad audiendum convenit, cognoscere ex me causam voluisse, sed ea quae scit mecum recognoscere 'and the purpose of the audience that has gathered to attend this trial is not, I conceive, to learn the facts of the case from me, but to join me in reviewing the facts that it knows already')

(b) rescisco 'get to know of (a fact not previously suspected)' (e.g., Plaut. Asin. 743 ne uxor resciscat metuit 'he is afraid of his wife finding out')

(c) cognosco 'get to know of' (e.g., Plaut. Men. 428-429 eadem ignorabitur,/ ne uxor cognoscat te habere 'it will look different, so that my wife won't find out that you have it')

Furthermore, one and the same prefix can have more than one function in Early and Classical Latin. Con-, for instance, has an actional function and indicates that a transformation takes place in consuesco 'get used to' (12b) or comedo 'eat up' (16a); it underlines the intensity of the action in commoror 'stay (on), remain, delay, wait' and condormio 'am fast asleep' (16b); and it means 'with, together' in congredior 'get together, meet' (16c). In the

16 For examples see Haverling (1994; 2000, 218ff, esp. 224-5, 229-31); thus I cannot entirely agree with the description in e.g., Hewson (1997, 327), who says that Latin calesco means 'I get warm' and the corresponding calui 'I got warm'.

17 See Haverling (2000, 362, 368); cf. also Haverling (1996b, 409ff). 
actional function it often interrelates with $a d-$ (16a), but when it means 'with, together' it often interrelates with dis- (16c): ${ }^{18}$

(16) (a) comedo 'eat up' - adedo 'eat away, eat into, nibble, wear down, exhaust'

(b) commoror 'stay (on), remain, delay, wait'; condormio 'am fast asleep'

(c) congredior 'get together, meet' - digredior 'go in different directions, depart from'

In other words, the system is rather complicated, and it is perhaps not surprising that it did not survive but was replaced by another one.

\subsection{Actionality in Late Latin}

The old semantic functions of prefixed and unprefixed and even suffixed verbs become less distinct in the later centuries, as the examples (1), (2), (3) and (4) indicate. As a result we now encounter new verbs which were not possible in the earlier periods. In the earlier periods the verbs with the sco-suffix generally had a dynamic sense, as for instance in aresco 'become drier, grow more and more dry'; but in Late Latin such verbs often have a non-dynamic function, as lippescit 'has red eyes' in St. Jerome, which can be compared to the expression lippis ... oculis in the Vulgate (17a). In the same period, the late 4th century, the historian Ammianus Marcellinus has the expression mensibus quinque delitescentes 'hiding for five months' (17b), where the durative temporal adverbial 'for five months' shows that delitescere has become synonymous with the old stative verb latere and means 'be hiding' (in Classical Latin delitescere means 'hide oneself, vanish'): ${ }^{19}$

(17) (a) Lia lippescit 'Leah has red eyes' (Hier. In Soph. 3.19 1. 582) - Lia lippis erat oculis 'Leah had red eyes' (Vulg. Gen. 29.17)

(b) mensibus quinque delitescentes 'hiding for five months' (Amm. 27.12.11)

A few previously impossible unprefixed $s c o$-verbs now appear in the sense of the prefixed verb; compare mutesco 'become mute, stop talking' in an edict from the year 399, preserved in the Codex Theodosianus (18b), and obmutesco in that sense in Cicero (18a): ${ }^{20}$

18 See Haverling (2000, 252-67, 267-72); cf. also Rosén (1992).

19 See e.g., Väänänen (1981, §316), and Haverling (2000, e.g., 53, 65, 178, 192, 247).

20 See Haverling $(2000,191,205 f)$.

Acta Linguistica Hungarica 50, 2003 
(18) (a) "De me" inquit "semper populus Romanus, semper omnes gentes loquentur, nulla umquam obmutescet vetustas ..." "Of me", he says, "shall the people of Rome and all nations ever speak, of me shall no far-off age ever cease to make mention", (Cic. Mil. 98; 1st c. BCE)

(b) ut eiusdem universis actibus antiquatis omnia mutescant tempora "so that, when all the administrative measures taken by him are rejected, there will be no further talk about this (scandal)' (Cod. Theod. 9.40.17; 399 CE)

Several of the new unprefixed verbs occur only in the grammarians. This is where we find the only example of tacesco (19a); the verb conticeo 'stop talking', which was very rare and poetic in the earlier periods, now sometimes occurs in prose (19a), and in the 6th century the famous grammarian Priscian regards it as the normal form corresponding to the perfect conticui (19b): ${ }^{21}$

(19) (a) taceo 'am silent, say nothing' (2nd c. BCE) - conticesco 'stop talking' (2nd c. BCE); 'be silent, say nothing' (Late Latin) - conticeo 'stop talking' (1st c. CE, poetry; Late Latin prose) - tacesco 'stop talking, am silent (?)' (7th c. CE, Virg. Gramm. Epist. 3.9)

(b) CONTICUERE - quae pars orationis est? Indicativo, coniugationis secundae. Cur secundae? Quia in praesenti tempore secundam personam in -es productam desinit, conticeo, contices ... 'Conticuere - what form is that? The indicative of the second conjugation. Why second? Because in the present tense the second person has the ending -es, conticeo, contices' (Prisc. Gramm. 3 p. 469; 6th c. CE)

Different prefixed verbs within the same family now occur in the same semantic function; in (20a) cognosco and agnosco occur in the function of novi 'I know' (cf. (12a)); in the Greek original (20b), as well as in the classical English translation of the Greek text (20c), we find the same verb in all these

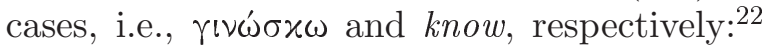

(20) (a) Ego sum pastor bonus: et cognosco meas, et cognoscunt me meae./ Sicut novit me Pater, et ego agnosco Patrem; et animam meam pono pro ovibus (Vulg. Ioh. 10.14 15)

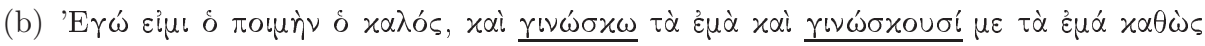

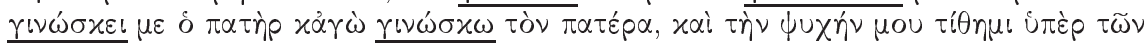
$\overline{\pi \rho \beta} \beta \dot{\alpha} \tau \omega \nu$ (NT Ioh. 10.14-15)

21 See Haverling (2000, 265f). Priscian also regards for instance exardeo and exareo (and not the more common exardesco and exaresco) as the infectum forms corresponding to exarsi 'caught fire' and exarui 'became dry': thus from this point of view he provides us with a rather odd description of Latin: cf. Haverling $(2000,339,457)$.

22 See Haverling (1996b, 410-2; 2000, 283). The Old Latin translations as well as the manuscripts of the Vulgate vary in this case, but the reading presented here has strong support and was chosen by Weber-Gryson (1994). 
(c) 'I am the good shepherd, and know my sheep, and am known of mine. As the Father knoweth me, even so know I the Father: and I lay down my life for the sheep' (King James version, Ioh. 10.14-15)

These changes pervade the whole verbal system and are found in all verbal families where there is an opposition between a telic prefixed verb and an atelic prefixed one. In Early and Classical Latin there is an opposition between panem edo 'I eat bread' (21a) and panem comedo 'I eat up the bread' (21b); but in Late Latin we often encounter the verb comedo in the sense 'eat (some) of', for instance in the famous passage in Genesis, where God tells Adam not that he must not eat up a certain kind of fruit but rather that he may not taste it at all $(21 \mathrm{c}):^{23}$

(21) (a) quasi mures semper edimus alienum cibum 'like mice, we are forever nibbling at some one else's food' (Plaut. Capt. 77)

(b) tam facile vinces quam pirum volpes comest 'you'll win as easily as a fox eats a pear' (Plaut. Most. 559)

(c) (Deus) praecepitque ei dicens: ex omni ligno paradisi comede. de ligno autem

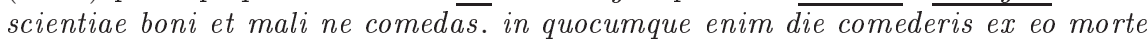

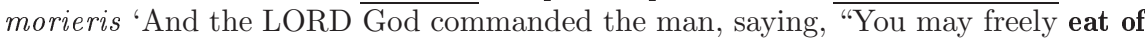
every tree of the garden; but of the tree of the knowledge of good and evil you shall not eat, for in the day that you eat of it you shall die."' (Vulg. Gen. 2.16-17)

As a result of these changes the semantic function expressed by several old verbs is more connected with their traditional use than with the originally actional character of their formation. In Classical Latin erubesco describes a change from one colour to another in a person's face and is used of people turning red with shame and embarrassment, whereas irrubescere means 'become somewhat red' (11b); but in Late Latin erubescere usually means 'be ashamed' (21a), and to indicate that somebody actually turns red in the face the 5th century bishop Sidonius Apollinaris uses a form of irrubesco (21b): ${ }^{24}$

(22) (a) Late Latin: erubesco 'am ashamed' - irrubesco 'turn red (in the face because of shame and embarrassment)'

(b) cum quodam prologo pudoris vultum modeste demissus inrubuit "with what I may call a prologue of modesty, he bashfully lowered his eyes and blushed' (Sidon. Epist. 8.6.6; 5th c. CE)

23 See Haverling (2000, 207, 262).

24 See Haverling (1996a, 177ff; 2000, 304). 
In Late Latin agnosco and cognosco are often confused with each other (20a), (23a), but in some respects the old functions are retained: agnosco is often, for instance in the Codex Theodosianus (a collection of laws published in $438 \mathrm{CE}$ ), a technical term for the assumption of legal duties or the acknowledgement of a specific legal situation or transaction (23b), which resembles the earlier usage. In the sense 'recognise, identify', however, agnosco and cognosco are often replaced by recognosco (23c), which in Classical Latin had the sense 'reconsider (something previously known)' (15a), or by the new verbs renosco and reagnosco (23a): ${ }^{25}$

(23) (a) LL cognosco = agnosco $=$ novi 'know' - recognosco 'recognise' (ca. $200 \mathrm{CE}$ ), renosco 'identify, recognise' (4th c. CE), reagnosco 'recognise, acknowledge' (6th c. $\mathrm{CE}$ )

(b) praedictam multam agnoscat 'he shall acknowledge his duty to pay the fine' (Cod. Theod. 4.8.8)

(c) dum illam (scil. idololatriam) non solum in manifestis recognoscimus 'as long as we recognise it (i.e., idolatry) not only when it is in the open' (Tert. Idol. 2.5; ca. $200 \mathrm{CE})$

Several of the prefixes are no longer productive in their actional functions in Late Latin, but the prefixes in- and $a d$ - are more productive than in earlier centuries. In the earlier periods in- emphasised the entrance into an action, but now it indicates dynamicity more generally. Several new sco-verbs prefixed with in- occur in the more literary Late Latin texts, where they replace the old unprefixed verbs. In Classical Latin we have the verbs crassesco and pinguesco in the sense 'become fatter' (24a), but in literary Late Latin we have incrassesco and impinguesco in the sense 'become fat' as well as the intransitive verbs incrasso and impinguo 'make fatter' (24b). In less literary Latin, however, we encounter the verbs incrasso and impinguo in the intransitive sense 'become fat' (24c):

(24) (a) crassesco 'grow thicker, thicken' (1st c. CE; e.g., Colum. 8.9.2) - pinguesco 'grow fatter' (1st c. BCE; e.g., Lucr. 5.899)

(b) incrassesco 'grow fatter' (4th c. CE; Rufin. Orig. in Psalm. 38 hom. 2.8) - incrasso 'make fatter' (3rd c. CE; e.g., Tert. Ieiun. 6.3) impinguesco 'grow thick, fat' (4th c. CE; Hier. In Is. 16.58.11) - impinguo 'make fat' (4th c. CE; Vulg. Sirach. 35.8)

(c) incrassavi 'became fat, grew fat' (3rd c. CE; Vet. Lat. Is. 6.10 in Cypr. Testim. 1.3) - impinguo 'become fat, grow fat' (4th c. CE; Apic. 8.7.5)

25 See Haverling (1996b, 411f; 2000, 88, 283, 368).

Acta Linguistica Hungarica 50, 2003 
In Early and Classical Latin in- is found in a number of causative verbs formed from adjectives, along the same lines as incrasso and impinguo 'make fat'. One example is invetero 'allow to become old, make old', which interrelates with the intransitive inveterasco 'grow old' (25a); but in Late Latin, in the 4 th century, we encounter the unprefixed veterasco as well as the intransitive invetero in the sense 'grow old' $(25 \mathrm{~b}):^{26}$

(25) (a) invetero 'allow to become old, make old' (1st c. BCE; e.g., Cic. Nat. deor. 2.5) inveterasco 'grow old, age, improve with age, mature' (2nd c. BCE; e.g., Ter. Hec. 12)

(b) veterasco 'grow old, become long-established' (4th c. CE; Vulg. Hebr. 1.11) - invetero 'grow old, age, improve with age, mature' (4th c. CE; Vulg. Is. 65.22)

This kind of formation with in and -are is common in Romance. ${ }^{27}$

$A d$ - is very productive in transitive as well as intransitive verbs in Late Latin, where verbs prefixed with $a d$ - often replace earlier verbs without the prefix; Plautus has the expression garrire nugas, but when Martianus Capella in the early 5th century alludes to this expression he writes nugulas aggarrire (26a); when Quintilian around $100 \mathrm{CE}$ talks about abbreviating a text he uses the unprefixed brevio, but in the 4th century Vegetius has the prefixed abbrevio in the same sense $(26 \mathrm{~b}):^{28}$

(26) (a) garrio 'chatter' (e.g., Plaut. Aul. 830, 2nd c. BCE) - aggarrio 'chatter' (e.g., Mart. Cap. 1.2 ; 5 th C. CE)

(b) brevio 'abbreviate' (e.g., Quint. Inst. 1.9.2; ca. $100 \mathrm{CE}$ ) - abbrevio 'abbreviate' (Veg. Mil. 3 praef.; 4th c. CE)

The original function of the actional $a d$ - was to emphasise the entrance into an action and graduality; this is lost in Late Latin, but the prefix retains the capacity to indicate dynamicity and in this new function it is productive in Late Latin and Romance. In Late Latin we find a growing number of verbs with $a d$ - which do not differ semantically from earlier verbs without the prefix. Ad- may even replace the $s c o$-suffix: in Early and Classical Latin we have vesperascit 'it is approaching evening' and advesperascit 'it starts to become evening' and in Late Latin we find the verb advesperat in the sense

26 See Haverling (1996a, 178ff; 2000, 153f, 182f, 302, 313f); for more examples of this development in Latin cf. Feltenius (1977). Many languages have deadjectival verbs meaning 'to become sth.' and 'to make sth. become sth.': cf. e.g., Beard (1995, 191ff).

27 See Rohlfs $(1954, \S \S 1015,1155)$; and Meyer-Lübke $(1894, \S 607)$ : cf. also Crocco GalèasIacobini (1993, esp. 38ff, 43, 48f).

28 See Thomas (1938, 86, 91), and Haverling (1999, 242ff; 2000, 285f). 
'become evening' (27a); parallel to Classical Latin vesparascente caelo (27b) we have Late Latin die advesperante (27c):

(27) (a) vesperascit 'it is approaching evening' (2nd c. $\mathrm{BCE}$ ) - advesperascit 'it starts to become evening' (2nd c. BCE) - advesperat 'it gets towards evening' (ca. $400 \mathrm{CE}$ )

(b) ut vesperascente caelo Thebas possent pervenire 'in order to be able to reach Thebes at nightfall' (Nep. Pelop. 2.5; 1st c. BCE)

(c) ad cellam eius iam die advesperante pervenimus 'we came to his room as the day was already turning into evening' (Cassian. Conl. 3.2.1; ca. $400 \mathrm{CE}$ )

In Romance $a d$ - is a productive prefix, for instance in verbs formed from adjectives. ${ }^{29}$

The new verbs with in- and $a d$ - replace not only old unprefixed scoverbs but also prefixed verbs of this type. In Early and Classical Latin we find condormisco and obdormisco in the sense 'fall asleep' and indormio in the sense 'sleep on, sleep during' (28a). But in Late Latin we encounter indormisco and indormio in the sense 'fall asleep' (28b); in this case French has chosen the form in in- (s'endormir) and Standard Italian that with ad(addormentarsi) (28c): $:^{30}$

(28) (a) dormio 'be asleep' (2nd c. BCE) - condormisco 'fall asleep' (2nd c. BCE) - obdormisco 'fall asleep' (1st c. BCE) — indormio 'sleep on, sleep during' (1st c. BCE)

(b) indormisco 'fall asleep' (4th c. CE) - indormio 'fall asleep' (4th c. CE); French s'endormir

(c) addormisco 'fall asleep' (6th c. CE) - addormio 'fall asleep' (5th c. CE); Standard Italian addormentarsi

These changes affect not only the infectum tenses, but, as already indicated above $(4 a-b)$, the use of the perfect too: in the earlier periods the unprefixed form is non-dynamic, whereas the prefixed form indicates a change of state, but in the later centuries this difference no longer applies. In the earlier periods of Latin we find the unprefixed perfect tense form tacui in the sense 'I have been silent' with the adverb adhuc 'so far' and in the phrase cum tacuisset 'as he had been silent, had not said anything' (13a); the prefixed form conticui means 'I have fallen silent' or 'I stopped talking' and cum conticuisset 'as he had stopped talking' (13b). The earliest dynamic examples of the form tacui 'stopped talking' are met with in Late Latin (29a); in the

29 See Rohlfs $(1954, \S 1001)$; and Meyer-Lübke (1894, §598); cf. also Crocco Galèas - Iacobini (1993, esp. 38ff, 43, 45-8).

30 See Haverling (1999, 244; 2000, 284, 304). 
same period cum tacuisset occurs in the sense 'as he had stopped talking'. We also have some examples of a hypercorrect use of the prefixed forms, for instance in conservative authors who try to write as people did a few centuries earlier; in the late 4th century the conservative pagan senator Symmachus writes hucusque conticui (29b), which corresponds to the formulation tacui adhuc in a passage of Plautus from the early 2nd century BC (13a): $:{ }^{31}$

(29) (a) 4th c. AD: ilico tacuit 'he immediately stopped talking' (Amm. 16.6.3) 4th/5th c. AD: cum tacuisset 'as he had stopped talking' (Aug. Ord. 1.6.16)

(b) 4th c. AD: hucusque conticui 'so far I have been silent' (Symm. Epist. 5.89)

This development affects not only related verbal pairs like taceo/tacui and conticesco/conticui but also the verbal system at large, as illustrated by the development of habui, 'I have had, I had'. In the sense 'she got a son' Classical Latin has such expressions as filium genuit, whereas filium habuit is nondynamic and means 'she had a son'. But in French and Italian we find phrases like elle eut un enfant and ebbe un bambino in the sense 'got a child', which shows that habui acquired a dynamic function in Vulgar Latin. ${ }^{32}$

Although the original semantic function of the prefixes seems in many cases to grow indistinct, a remarkable number of new prefixed verbs are created even in the later periods, often by authors well trained in Classical Latin (as, for instance, St. Jerome, St. Augustine and the pagan Symmachus). These people knew and avoided most of the changes which had taken place in the language since the Classical norm was defined in the 1st century BCE, and which we can observe in the vulgar texts from their period. They were, however, unaware of the changes in the actional functions of the prefixes. The use of prefixed words therefore becomes a stylistic device: old words or kinds of word formation were reinterpreted by skilful authors playing with the possibilities of their language; and in a certain kind of archaising Late Latin we encounter a number of prefixed words in which the prefixes seem to have no other function than that of an exotic adornment. ${ }^{33}$ Several old kinds of word formation therefore seem more vigorous in Late Latin than they probably were in real life. ${ }^{34}$

31 See Haverling (2000, 218ff, 224f; cf. also 1994, 49ff).

32 See Haverling $(2000,242)$.

33 On this development in Late Latin see Haverling $(1988,35,102,110)$ and the literature quoted there; cf. also Haverling (2000, e.g., 271f, 302ff, 320ff, 346, 356, 382ff).

34 Affixes which are losing their original semantic function usually become rare and unproductive: cf. Aronoff-Anshen (1998, 243). 
Various critical problems in the texts are connected with this development. In some manuscripts we find $s c o$-verbs which probably never existed, and now and then, in the manuscript tradition of a classical author we have prefixed forms which reflect the linguistic habits of a much later period. ${ }^{35}$ In other cases odd readings in medieval manuscripts hide a new verb dating from Late Antiquity and which was no longer understood by scribes in the Middle Ages. ${ }^{36}$

\subsection{Changes triggered by the development in the actional system}

The change in the actional system is connected in various ways with other changes in the language. I shall now briefly mention two such changes, namely (1) an altered relationship between the perfect and the imperfect tense forms and (2) the development of definite and indefinite articles and various partitive expressions in the Romance languages.

As we have seen, there is a change in the relationship between the unprefixed perfect tense form tacui and the prefixed form conticui from Early to Late Latin. In Late Latin the unprefixed form could be used in both the dynamic and non-dynamic sense, it could mean 'stopped talking' as well as 'was silent' ((4b), (29a-b)). In my view these changes affect the relationship between the perfect and imperfect tenses of non-dynamic verbs. ${ }^{37}$ In Classical Latin tacui serves to give an overview of past situations, for instance in 'how could Clodius remain silent ...?' (30a), or in descriptions of people who are speechless or simply refuse to say anything in reply to an important statement (30b). The imperfect tacebam is used with expressions that indicate contemporaneity with some other event or situation (30c) and in descriptions of habit (30d):

35 For instance we have an example of addormisceret 'fell asleep' in the tradition of Suetonius (Claud. 8), who elsewhere uses obdormisceret in this sense (Claud. 33.2, Vesp. 4.4); the lexicographer Nonius Marcellus was sometimes careless when quoting from classical texts, and it is probable that we owe inseniscentis, in the sense of senescentis, to him rather than to Cicero (Cic. Ac. frg. 6 in Non. pp. 121.29-122.1) and that he and not Sisenna wrote subito tacuit, for subito conticuit (Sisenna Hist. 45 in Non. p. 361.20-22): see Haverling (2000, 56, 224, 284, 306).

36 One example is the verb addentire in the sense 'get teeth' probably found in the Old Commentary to the Late Latin translation of the Hippocratic Aphorisms (Aph. 3.25). In Classical Latin we have the verb dentire 'get teeth', but in the manuscripts preserving this text we have odd readings which seem to indicate that there was a verb addentire in Late Latin: cf. Haverling (1999, 243; 2000, 286f; forthcoming).

37 See Haverling (1998; 2000, 241-46; 2001). 
(30) (a) Quo modo autem iis quos tu scribis et de re dicentibus et ut referretur postulantibus Clodius tacuit? ... 'And how is it that Clodius held his tongue, when the men you mention were talking about the case and asking for a motion?' (Cic. Att. 3.15.6)

(b) Aspasia autem sermonem cum ipso Xenophonte instituit. 'Quaeso', inquit, 'Xenophon, si vicinus tuus equum meliorem habeat, quam tuus est, tuumne equum malis an illius?' 'Illius', inquit. ... 'Quid, si uxorem meliorem habeat, quam tu habes, utrum 〈tuamne an〉 illius malis?' Atque hic Xenophon quoque ipse tacuit 'But Aspasia then began to speak to Xenophon. "I wish you would tell me, Xenophon", she said, "if your neighbour had a better horse than yours, would you prefer your horse or his?" "His", was his answer. ... "Now, if he had a better wife than you have, would you prefer yours or his?" And at this Xenophon, too, himself was silent.' (Cic. Inv. 1.52)

(c) Me vero non illius oratio (scil. movit), sed eorum taciturnitas, in quos illa oratio tam improba conferebatur; qui tum quamquam ob alias causas tacebant, tamen hominibus omnia timentibus tacendo loqui, non infitiando confiteri videbantur 'My resolution was not shaken by his language, but by the obstinate silence of those to whom that shameless language was made to refer, who at that time remained silent for other reasons, yet to men who were afraid of everything they seemed by silence to speak, and by denying to confess' (Cic. Sest. 40)

(d) At illi ... parati erant pro domino porrigere cervicem, periculum inminens in caput suum avertere; in conviviis loquebantur, sed in tormentis tacebant 'But they (i.e., the slaves of former days) ... were ready to bare their necks for their master, to bring upon their own heads any danger that threatened him; they spoke at the feast, but kept silent in torture' (Sen. Epist. 47.4)

In the Vulgate, however, we find the imperfect tense of tacere when Jesus does not answer the high priest's questions (31a) or the Pharisees that of Jesus (31b); and the imperfect tense is found when St. Augustine describes how participants in a discussion are rendered speechless by the statements of others (31c):

(31) (a) Et surgens princeps sacerdotum ait illi: 'Nihil respondes ad ea quae isti adversum te testificantur?' Iesus autem tacebat 'And the high priest arose, and said unto him, "Answerest thou nothing? what is it which these witness against thee?" But Jesus held his peace' (Vulg. Math. 26.62-63)

(b) Et dicit eis: 'Licet sabbatis bene facere an male, animam salvam facere an perdere?' At illi tacebant. 'And he saith unto them, "Is it lawful to do good on the sabbath days, or to do evil? to save life, or to kill?" But they held their peace' (Vulg. Marc. 3.4-5)

(c) 'Nam quaero, ex te, quaeso, inquit, iustusne sit Deus?' - Tacebat ille, nimis, ut postea retulit, admirans et horrens subito condiscipuli ... sermonem "But please tell me, what do you think, is God righteous?" The other one remained silent, as he afterwards told me, because he was astonished and horrified by the utterance made by his fellow student' (Aug. Ord. 1.7.19; ca. $400 \mathrm{CE}$ ) 
In similar cases Cicero used the form tacui (30a-b). Thus the borderline between the semantic fields of the perfect tense form tacui and the imperfect tense tacebam seems to have moved slightly. These changes are reflected in the various translations of the Bible, for instance in the translation of the

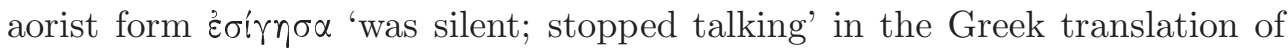
the Old Testament, the so-called Septuagint (32a). In the Vulgate text of the Psalms, that is, Jerome's translation from the Greek (32b) and from the Hebrew (33a), as well as in a Vetus Latina manuscript (32b), we find the perfect tense form; but in another Vetus Latina manuscript and in the Latin translation of a Greek text containing a quotation of this passage from the Septuagint, Athanasius' Vita Antonii, we encounter the imperfect tense (32c); the English translator interpreted the Hebrew original as non-dynamic (33b):

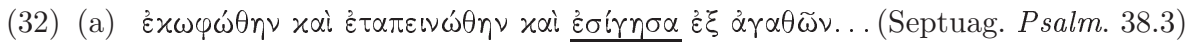

(b) obmutui et humiliatus sum et silui a bonis (Vulg. Psalm. 38.3 from Greek; cf. obsurdui in Vet. Lat. cod. 300 ibid.)

(c) "Cum asteterit peccator in conspectu meo, insurdabar et humiliabar et tacebam a bonis" (Vet. Lat. Psalm. 38.3 in Vita Anton. 27 p. 41.17-18; cf. mutus tacebam in Vet. Lat. cod. 136 ibid.)

(33) (a) obmutui silentio tacui de bono et dolor meus conturbatus est (Vulg. Psalm. 38.3 from Hebrew)

(b) 'I was dumb with silence, I held my peace, even from good; and my sorrow was stirred' (King James version Psalm. 39.2)

It is possible that those who chose the perfect tense in $(32 \mathrm{~b})$ interpreted the Greek aorist as a dynamic form, whereas those who preferred the imperfect tense in (32c) regarded it as non-dynamic; but it is also possible that St. Jerome used the prefixed obmutui in a non-dynamic sense, i.e., 'I was dumb' (cf. Symmachus' use of conticui in the sense 'have been silent' in (29b)). The example shows in both cases that by now the imperfect tense was the less ambiguous choice in the description of a non-dynamic situation in the past.

In Early and Classical Latin there is an opposition between panem edo 'I eat bread' and panem comedo 'I eat up the bread' ((2a), (21a-b)), but in Late Latin the prefixed verb comedo is sometimes used in the sense 'eat (some) of' (21c). This development is probably connected with the development of definite and indefinite articles as well as with the introduction of partitive expressions in Romance. In many languages the opposition between an atelic expression like (a) 'I eat bread' and a telic one like (b) 'I eat up the bread' is 
expressed by a definite article, underlining the telicity in (b), or by a partitive expression, indicating the atelicity of (a). ${ }^{38}$

There are certainly traces of the development towards the Romance system of definite and indefinite articles in vulgar Late Latin. The correct interpretation of many single instances has, however, been disputed and the most authoritative scholars who have dealt with the matter agree that there was no systematic use of such devices in Latin. ${ }^{39}$ There seems in fact to be no Latin example of an article clearly expressing the telicity once expressed by the prefix: i.e., no example of panem comedo 'I eat up a/the bread' being replaced by *panem unum comedo or *panem illum comedo.

What we do have, however, are partitive expressions with the prefixes $d e$, ex or $a b$ which underline the atelicity once indicated by the unprefixed verb. In Early and Classical Latin we find bibo 'drink, drink (some) of' (34a) as well as ebibo 'drink up' (34b) with an object in the accusative; a partitive expression in the genitive is found only when there is a word requiring it, for instance the adverb largiter 'in great quantity' with poto 'drink' in (35a). In a few cases with $d e$ and the ablative the semantic function is not partitive; the expression de alieno in Plautus (35b) means 'at someone else's expense' (compare edimus alienum cibum 'we are nibbling at someone else's food' in $(21 \mathrm{a})):^{40}$

(34) (a) (Mulier) multitatur, si vinum bibit 'a woman is regularly sentenced to pay a fine, if she drinks wine' (Cato Orat. frg. 221)

(b) qui ... acetum, quod forte secum habebat, ebibit et liberatus est "who drank up the vinegar he happened to have with him, and was saved' (Cels. 5.27.4)

(35) (a) veteris vini largiter / ut dies noctesque potet 'that she may drink a lot of old wine day and night' (Plaut. Truc. 903-904)

(b) Plaut. Poen. 534: ubi bibas, edas de alieno, quantum velis usque ad fatim 'where you can drink and eat as much as you can want and hold, at another man's expense'

38 See e.g., Comrie $(1989,127)$ and Croft (1990, 177); Abraham (1997, 36, 47) mentions that e.g., Old High German normally uses the partitive genitive with the verb drincan 'drink'; cf. also Philippi (1997, 79ff).

39 See e.g., Löfstedt (1942, 358-82), Hofmann-Szantyr (1965, §106) and Väänänen $(1981, \S 215)$. The literature on this problem is vast, and the views on when there is a genuine use of definite and indefinite articles in Latin vary a great deal; Selig (1991, 19 24) gives an overview of the earlier discussion.

40 In early Germanic, e.g., Gothic, there is an interaction between the actional markers on the verbs and the cases, i.e., atelic verbs are combined with the partitive genitive and telic verbs with the accusative; this system was eventually replaced by the use of articles: cf. Abraham (1997) and Philippi (1997).

Acta Linguistica Hungarica 50, 2003 
In Late Latin, however, we sometimes find a partitive expression which seems to underline the atelicity of the action. Thus in (36) we have bibo 'drink (some) of' with a partitive expression de vino, and in (37a) a partitive expression de cadavere with the prefixed verb comedo meaning 'eat (some) of'; by contrast the latter verb with an object in the accusative means 'eat up' in $(37 b)$ :

(36) de vino eius biberunt gentes et ideo commotae sunt 'the nations have drunken of her wine; therefore the nations are mad' (Vulg. Ier. 51.8)

(37) (a) non comedit leo de cadavere nec laesit asinum 'the lion had not eaten of the carcase, nor torn the ass' (Vulg. 1 Reg. 13.28)

(b) et panes propositionis comedit quos non licebat ei edere 'he ... did eat the shewbread, which was not lawful for him to eat' (Vulg. Matth. 12.4)

However, in (36) where the Vulgate has de vino, the Septuagint too has a

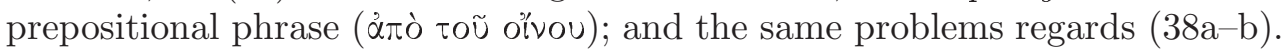
In (38a) we seem to have two atelic expressions, one with an object in the accusative (fructum eius non edit 'does not eat of its fruit') and one with a partitive expression (de lacte ... manducat 'does not eat of the milk'); but the Greek original has a definite article in the first case ('does not eat the fruit') and a prepositional phrase in the second (38b):

(38) (a) quis plantat vineam et fructum eius non edit quis pascit gregem et de lacte gregis non manducat "who planteth a vineyard, and eateth not of the fruit thereof? or who feedeth a flock, and eateth not of the milk of the flock?' (Vulg. 1 Cor. 8.7)

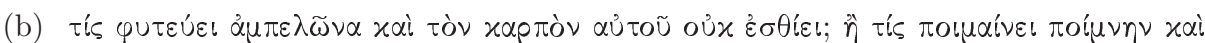

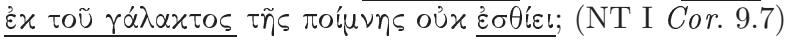

The trouble with these and almost all the other examples found in Late Latin is that they are found in texts translated from Greek, or at least possibly influenced by translations from Greek, or, in a couple of cases, written by Greeks writing on medicine in Latin. There are also a few examples in Christian authors referring to the Bible. In other words, these expressions were possible in Late Latin, but there is yet no systematic use of them as a device to indicate atelicity. 


\section{Conclusion}

In Early and Classical Latin the verbal system is characterised by a rich and complex system in which prefixes are used to render verbs telic or to emphasise the beginning or end of a process or activity. The opposition between non-dynamicity and dynamicity or between transitivity and intransitivity is expressed by various suffixes. In the perfect there is an opposition between non-dynamic unprefixed verbs and dynamic prefixed ones.

In the later centuries this system breaks down, and there is a blurring of the semantic distinctions between the prefixed and unprefixed verbs and often also of those between the prefixes themselves. We then find the old verbs in semantic functions similar but not identical to those they had in the earlier periods. It often happens that a verb which in the earlier centuries had been commonly associated with a certain semantic context acquires a new lexical meaning as a result of this association. Prefixes formerly used to emphasise the beginning or the gradual character of a process now indicate dynamicity and change more generally, and previously transitive formations are used with an intransitive function.

These changes pervade the whole verbal system in Latin and affect the semantic relationship between the perfect and imperfect tenses as well as the development of definite and indefinite articles and partitive expressions with the preposition de. In Late Latin the ingressive sense is more often expressed by the unprefixed perfect tense form and the non-dynamic situation in the past by the imperfect tense form. But the use of articles or partitive expressions to indicate systematically the difference between atelic and telic actionality belongs to Romance rather than to Latin. We have a few examples of new partitive expressions with verbs meaning 'eat' and 'drink', but there is no consistent use of this device to indicate atelicity.

\section{References}

Abraham, Werner 1997. Case, aspect and referentiality. In: van Kemenade-Vincent (1997, 29$61)$.

Aronoff, Mark-Frank Anshen 1998. Morphology and the lexicon: lexicalization and productivity. In: Andrew Spencer-Arnold M. Zwicky (eds) The handbook of morphology, 237-47. Blackwell, Oxford \& Malden MA.

Beard, Robert 1995. Lexeme-morpheme base morphology. SUNY Press, Albany NY.

Bertinetto, Pier Marco-Denis Delfitto 2000. Aspect vs. actionality: why they should be kept apart. In: Dahl (2000, 189-225).

Acta Linguistica Hungarica 50, 2003 
Bybee, Joan 1985. Morphology: a study of the relation between meaning and form. John Benjamins, Amsterdam \& Philadelphia.

Bybee, Joan - Revere Perkins - William Pagliuca 1994. The evolution of grammar: tense, aspect and modality in the languages of the world. The University of Chicago Press, Chicago \& London.

Comrie, Bernard 1978. Aspect. An introduction to the study of verbal aspect and related problems. Cambridge University Press, Cambridge.

Comrie, Bernard 1989. Language universals and linguistic typology (Second edition). Blackwell, Cambridge MA \& Oxford.

Crocco Galèas, Grazia - Claudio Iacobini 1993. Lo sviluppo del tipo verbale parasintetico in latino: i prefissi ad-, in-, ex-. In: Quaderni Patavini di Linguistica 12:31-68.

Croft, William 1990. Typology and universals. Cambridge University Press, Cambridge.

Dahl, Östen (ed.) 2000. Tense and aspect in the languages of Europe. Mouton de Gruyter, Berlin \& New York.

Feltenius, Leif 1977. Intransitivizations in Latin. Studia Latina Upsaliensia 9. Ph.D. dissertation, University of Uppsala, Uppsala.

Haverling, Gerd 1988. Studies on Symmachus' language and style. Studia Graeca et Latina Gothoburgensia XLIX. Ph.D. dissertation, University of Göteborg, Göteborg.

Haverling, Gerd 1994. On the sco-suffix, on prefixes and on the development of the Latin verbal system. In: József Herman (ed.) Linguistic Studies on Latin: Selected Papers from the 6th International Colloquium on Latin Linguistics, Budapest 23-27 March 1991. Studies in Language Companion Series 28, 41-53. John Benjamins, Amsterdam \& Philadelphia.

Haverling, Gerd 1996a. On sco-verbs, on prefixes and on semantic functions. In: Hannah Rosén (ed.) Aspects of Latin: papers from the Seventh International Colloquium on Latin Linguistics, Jerusalem, April, 1993. Innsbrucker Beiträge zur Sprachwissenschaft 86, 16980. Institut für Sprachwissenschaft der Universität Innsbruck, Innsbruck.

Haverling, Gerd 1996b. Some more remarks on sco-verbs, prefixes and semantic functions. In: Alfred Bammesberger - Friedrich Heberlein (eds) Akten des VIII. internationalen Kolloquiums zur lateinischen Linguistik. Indogermanische Bibliothek, Reihe 3, Untersuchungen, 401-14. Universitätsverlag C. Winter, Heidelberg.

Haverling, Gerd 1999. Über Aktionsarten und Präfixe im Spätlatein. In: Hubert PetersmannRudolf Kettemann (eds) Latin vulgaire - Latin tardif V: Actes du $\mathrm{V}^{\mathrm{e}}$ Colloque International sur le latin vulgaire et tardif, Heidelberg, 5-8 septembre 1997. Bibliothek der klassischen Altertumswissenschaften N.F. 2:105, 235-49. Universitätsverlag C. Winter, Heidelberg.

Haverling, Gerd 2000. On sco-verbs, prefixes and semantic functions: a study in the development of prefixed and unprefixed verbs from Early to Late Latin. Studia Graeca et Latina Gothoburgensia LXIV (Acta Universitatis Gothoburgensis). University of Göteborg, Göteborg.

Haverling, Gerd forthcoming. Sur le latin vulgaire dans la traduction "ravennate" des Aphorismes d'Hippocrate. In: Heikki Solin (ed.) Latin vulgaire-latin tardif VI: Acta sexti conventus internationalis Latinitatis vulgaris et posterioris. Actes du $\mathrm{VI}^{\mathrm{e}}$ Colloque International sur le latin vulgaire et tardif, Helsinki 28 août-2 septembre 2000. OlmsWeidmann, Hildesheim \& Zürich \& New York. 
Hewson, John 1997. From Latin to Modern Romance. In: John Hewson - Vit Bubenik (eds) Tense and aspect in Indo-European languages: theory, typology, diachrony. Current issues in linguistic theory 145, 314-30. John Benjamins, Amsterdam \& Philadelphia.

Hofmann, Johann Baptist - Anton Szantyr 1965. Lateinische Syntax und Stilistik. In: Manu Leumann - Johann Baptist Hofmann - Anton Szantyr (eds) Lateinische Grammatik. Zweiter Band. Handbuch der Altertumswissenschaft II.2.2. C.H. Beck'sche Verlagsbuchandlung, München.

Johanson, Lars 2000. Viewpoint operators in European languages. In: Dahl (2000, 27-187).

Josephson, Folke 1977. On the function of the Gothic preverb ga-. In: Indogermanische Forschungen $81: 152-75$.

Keller, Madelaine 1992. Les verbes latins à infectum en -sc-, étude morphologique (à partir des formations attestées dès l'époque préclassique). Collection Latomus 216. Latomus, Bruxelles.

Kemenade, Ans van - Nigel Vincent (eds) 1997. Parameters of morphosyntactic change. Cambridge University Press, Cambridge.

Kuryłowicz, Jerzy 1964. The inflectional categories of Indo-European. Indogermanische Bibliothek, Dritte Reihe: Untersuchungen. Universitätsverlag C. Winter, Heidelberg.

Lehmann, Christian 1995. Latin predicate classes from an onomasiological point of view. In: DE USU: Études de syntaxe latine offertes en hommage à Marius Lavency, 163-73. Peeters, Louvain-La-Neuve.

Leumann, Manu 1977. Lateinische Laut- und Formenlehre. In: Manu Leumann- Johann Baptist Hofmann - Anton Szantyr (eds) Lateinische Grammatik. Erster Band. Handbuch der Altertumswissenschaft II.2.1. C.H. Beck'sche Verlagsbuchandlung, München.

Lloyd, Albert L. 1979. Anatomy of the verb: the Gothic verb as a model for a unified theory of aspect, actional types, and verbal velocity. John Benjamins, Amsterdam \& Philadelphia.

Löfstedt, Einar 1942. Syntactica. Studien und Beiträge zur historischen Syntax des Lateins. Erster Teil: Syntaktisch-stilistische Gesichtspunkte und Probleme. Skrifter utgivna av Kungl. humanistiska vetenskapssamfundet i Lund 10:2 (Second edition). C.W.K. Gleerup, Lund.

Meyer-Lübke, Wilhelm 1894. Grammatik der Romanischen Sprachen, Zweiter Band: Formenlehre. Reisland, Leipzig.

Philippi, Julia 1997. The rise of the article in the Germanic languages. In: van KemenadeVincent (1997, 62-93).

Pinkster, Harm 1990. Latin syntax and semantics (transl. H. Mulder, Romance Linguistics). Routledge, London \& New York.

Rix, Helmut (ed.) 1998. Lexikon der indogermanischen Verben. Die Wurzeln und ihre Primärstammbildungen. Ludwig Reichert Verlag, Wiesbaden.

Rohlfs, Gerhard 1954. Historische Grammatik der Italienischen Sprache und ihrer Mundarten, Band III: Syntax und Wortbildung. Francke, Bern.

Rosén, Haim B. 1992. Die Komposita mit co(n)- in funktioneller und vergleichender Sicht. In: Oswald Panagl - Thomas Krisch (eds) Latein und Indogermanisch-Akten des Kolloquiums der Indogermanischen Gesellschaft, 357-67. Institut für Sprachwissenschaft der Universität Innsbruck, Innsbruck. 
Selig, Maria 1991. Die Entwicklung der Nominaldeterminanten im Spätlatein: Romanischer Sprachwandel und lateinische Schriftligkeit. Scriptoralia 26. Ph.D. dissertation, University of Freiburg, Tübingen.

Smith, Carlota S. 1997. The parameter of aspect. Kluwer, Dordrecht.

Thesaurus Linguae Latinae. Leipzig 1900-.

Thomas, François 1938. Recherches sur le développement du préverbe latin ad-. C. Klincksiek, Paris.

Vendler, Zenon 1957. Verbs and times. In: The Philosophical Review 66 :143-60.

Vendler, Zenon 1967. Linguistics in philosophy. Cornell University Press, Ithaca NY.

Väänänen, Veikko 1981. Introduction au Latin vulgaire. Bibliothéque Française et Romane, Ser. A, Vol. 6, 3rd ed. C. Klincksiek, Paris.

Weber, Robert - Roger Gryson 1994. Biblia sacra iuxta vulgatam versionem (Fourth edition). Deutsche Bibelgesellschaft, Stuttgart.

Address of the author: Gerd Haverling

Department of Classical and Romance Studies

University of Aarhus

Ndr. Ringgade 1, Bygn. 414

DK - 8000 Århus C

oldgha@hum.au.dk 